\title{
IN VITRO CONSUMPTION OF CAULERPA TAXIFOLIA (CHLOROPHYTA) BY ACCUSTOMED AND NON-ACCUSTOMED PARACENTROTUS LIVIDUS (ECHINOID): SEASONAL VARIATIONS
}

\author{
ANNE GANTEAUME, JULIE GOBERT, PASCALE MALESTROIT, VALÉRIE \\ MÉNAGER, PATRICE FRANCOUR AND CHARLES-FRANÇOIS BOUDOURESQUE \\ Laboratoire de Biologie Marine et d'Ecologie du Benthos, EP CNRS no. 75, Faculté des Sciences de Luminy, \\ F-13288 Marseille cédex 9, France
}

In vitro short time experiments (a few weeks) show that daily ingestion by Paracentrotus lividus (Echinodermata: Echinoidea) is weak $\left(0-81 \mathrm{mg} \mathrm{DW} \mathrm{d}^{-1}\right.$ ind $\left.^{-1}\right)$ for Caulerpa taxifolia (Chlorophyta), compared to the data recorded with an almost totally avoided brown alga, Cystoseira compressa (24-137 $\mathrm{mg} \mathrm{DW} \mathrm{d}^{-1}$ ind $\left.^{-1}\right)$ and with a preferred brown alga, Halopteris scoparia (79-397 $\mathrm{mg} \mathrm{DW}^{-1}$ ind $\left.^{-1}\right)$. There is no significant difference between spring (when the toxic metabolite content is at its minimum) and summer-autumn (when it is at its maximum). In contrast, the absorption rate of the sea urchin fed on Caulerpa taxifolia is significantly weaker in spring than in summer-autumn. Overall, the daily absorbed weight is negative in spring with $C$. taxifolia (compared with $18 \mathrm{mg} \mathrm{DW} \mathrm{d}^{-1}$ ind $^{-1}$ with Cystoseira compressa and $25 \mathrm{mg} \mathrm{DW} \mathrm{d}^{-1}$ ind $^{-1}$ with $H$. scoparia). It has also been demonstrated that $P$. lividus becomes accustomed to Caulerpa taxifolia, at least for short time experiments: the echinoid consumes greater quantities of this alga especially if it is fresh when it has already consumed it previously.

\section{INTRODUCTION}

Since 1984, the introduced alga Caulerpa taxifolia (Vahl) C. Agardh (Chlorophyta) has steadily spread along the Mediterranean coast of France (Meinesz \& Hesse, 1991; Meinesz et al., 1993a,b, 1994, 1995), Italy (Morucci et al., 1994) and Spain (Pou et al., 1993; Ballesteros et al., 1994); the area covered increased annually between 1984 and 1991 by a factor of six (Boudouresque et al., 1992a,b; Boudouresque \& Gómez-Garreta, 1992).

Contrary to observations in tropical seas, C. taxifolia meadows in the Mediterranean are very dense, and frond length may reach $85 \mathrm{~cm}$ (Meinesz \& Hesse, 1991; Villèle \& Verlaque, 1995). Most substrate types can be colonized: rock, sand, mud, dead rhizomes (or shoots) of Posidonia oceanica (Linnaeus) Delile, sea grass meadows (Meinesz et al., 1993), from the surface to $100 \mathrm{~m}$ depth (Belsher et al., 1994), with an optimum growth rate between 2.5 and $35 \mathrm{~m}$ depth.

Caulerpa taxifolia presents an optimum growth rate between 20 and $30^{\circ} \mathrm{C}$ (Komatsu et al., 1994). This introduced alga synthesizes several secondary metabolites (particularly caulerpenyne) in greater quantities than in the tropical seas (Guerriero et al., 1992, 1994; Lemée et al., 1993). 
The echinoid Paracentrotus lividus (Lamarck, 1816) is a major grazer in Mediterranean phytobenthic communities (Verlaque \& Nédélec, 1983). Its diet is mainly herbivorous and it presents very algal marked preferences (Traer, 1980; Verlaque \& Nédélec, 1983; Verlaque, 1987; Frantzis et al., 1988; Rico, 1989; Frantzis \& Grémare, 1992). In vitro studies on its feeding behaviour toward C. taxifolia show that this alga is not particularly avoided in winter-spring, but is avoided in summerautumn, at least in long duration (three months) experiments (Lemée et al., 1994a; Boudouresque et al., 1996). At this time, the alga's toxicity is at its highest (Lemée et al. 1993). Moreover, Gobert (1992) has shown in vitro that the food ration of P. lividus, when it is fed on a preferred alga (Rissoella verruculosa (Bertoloni) J. Agardh), decreases in the presence of $C$. taxifolia. This may be due to the leaching of toxic metabolites (or of their degradation products) by this alga. In situ, Ruitton \& Boudouresque (1994) noted, at Cap Martin (Alpes-Maritimes, France), that the sea urchins moved away from the invaded area, toward not yet invaded substrates. Moreover, previous long term studies have shown that, when P. lividus is fed exclusively on C. taxifolia, certain of its biotic parameters are affected: decrease of the gonadal growth rate, increase of the righting time (time taken to recover a normal position, mouth down, from being turned over), loss of spines (Lemée et al., 1994b; Boudouresque et al., 1996). Since the area occupied by C. taxifolia exceeds 1300 ha between Nice and Menton (Vaugelas et al., 1994), the echinoid populations in the Alpes-Maritimes area might be affected. The antimitotic properties of caulerpenyne on sea urchin eggs have been demonstrated (Lemée et al., 1993).

The questions addressed in this study are:

(1) Is there any variation of daily ingestion and absorption rate, in short duration experiments, when P. lividus is fed on C. taxifolia, between spring (when the alga synthesizes few secondary metabolites) and summer-autumn (when secondary metabolite content is maximum)?

(2) If C. taxifolia is maintained for a long time in aquaria, is its ingestion rate altered (at equal temperatures) as compared to the freshly collected alga?

(3) Do sea urchins become accustomed to C. taxifolia, and/or do they react to the repellent effect of $C$. taxifolia?

\section{MATERIALS AND METHODS}

Experimental closed circuit aquaria contained $20 \mathrm{dm}^{3}$ of artificial sea-water. They were equipped with an air pump, a filter and a plastic grid bottom to avoid faeces ingestion. They were situated in a culture room with controlled temperature and exposed to natural light. The artificial sea-water $\left(38 \mathrm{~g} \mathrm{dm}^{-3}\right.$ of aquarium salt Ocean ${ }^{\mathrm{i}}$, Aquarium Systems) was totally renewed every three days. During transport and during the experiments, the temperature was adjusted to the sea temperature at the time of collection of the Caulerpa taxifolia (sea-water temperature in spring: $13-17^{\circ} \mathrm{C}$; in summer-autumn: $19-25 \mathrm{C}$ ). 
The sea urchins Paracentrotus lividus, with a test diameter between 4 and $6 \mathrm{~cm}$ (measured at the ambitus, without spines) were collected at Saména (Marseilles, Bouches-du-Rhône, France) between 2 and $3 \mathrm{~m}$ depth, in an overgrazed zone where the trophic resource is a limiting factor. The sea urchins were replaced at the beginning of each experiment ('non-accustomed echinoids': NAE) except in experiments 8 and 11 to 14 (Table 1), where the same sea urchins were kept from one experiment to another, in order to determine in summer-autumn a possible ability to become accustomed to C. taxifolia ('accustomed echinoids': AE).

The green alga C. taxifolia was collected at Cap Martin (Alpes-Maritimes, France) at $6 \mathrm{~m}$ depth. The whole thallus of this alga (fronds, stolons, rhizoids) was used in each experiment. The brown alga Cystoseira compressa (Esper) Gerloff \& Nizamuddin came from Cap Martin and Sausset-les-Pins (Bouches-du-Rhône, France). The brown alga Halopteris scoparia (Linneaus) Sauvageau was collected at Saména (Marseilles, Bouches-du-Rhône, France) at $5 \mathrm{~m}$ depth. These last two algae, the first almost totally avoided, the second preferred (Frantzis \& Grémare 1992), were taken as controls (experiments 17-27 and 28-39).

In order to verify whether $C$. taxifolia becomes more appetizing after a long period in the aquarium, experiments were performed with $C$. taxifolia in two different states: one referred to as 'old' $(\mathrm{O})$, maintained at least one week in aquaria before the beginning of the experiment (experiments $5,6,8,10,12$ ), the other referred to as 'fresh' (F) collected less than a week previously (experiments 1-4, 7, 9, 11, 13-16).

For each experiment, ten sea urchins were placed in each aquarium, without fasting. The fresh alga provided was weighed and completed to $50 \mathrm{~g}$ (strained wet weight) every day. The control aquaria containing $50 \mathrm{~g}$ of alga alone served to determine the possible growth or degeneration of the three species. Before each weighing, a standardized straining protocol was carried out: rough straining, centrifugation (2500 rpm for $1 \mathrm{~min}$; rotor diameter Jouan E82 ${ }^{\overline{\mathrm{B}}} 14.5 \mathrm{~cm}$ ), then weighing of the fresh weight (at least $0.1 \mathrm{~g}$ ). For $H$. scoparia, manual centrifugation at $420 \mathrm{rpm}$ for $1 \mathrm{~min}$ was carried out before centrifugation at $2500 \mathrm{rpm}$.

The ingested wet weight was calculated as follows:

Ingested wet weight $=W \exp _{0}-W \exp _{1}-\left(W_{t_{0}}-W_{t_{1}}\right)$

where: $W \exp _{0}$ is the weight of alga at time 0 in the experimental aquarium; Wexp $\mathrm{e}_{1}$ the weight of alga at time 1 in the experimental aquarium; $W t_{0}$, weight of alga at time 0 in the control aquarium; $\mathrm{Wt}_{1}$, weight of alga at time 1 in the control aquarium.

A conversion factor ingested dry weight/ingested wet weight was calculated for the three species. This factor is 0.11 for C. taxifolia, 0.16 for Cystoseira compressa and 0.29 for H. scoparia.

When new sea urchins are used ('non-accustomed echinoids'), the first three days of experiment are not taken into account. During this time, sea urchins in fact egest algae ingested before the experiments; according to Kempf (1962) and Powis de Tenbossche (1978), the intestinal transit lasts from about one day and a half to three days, respectively. 


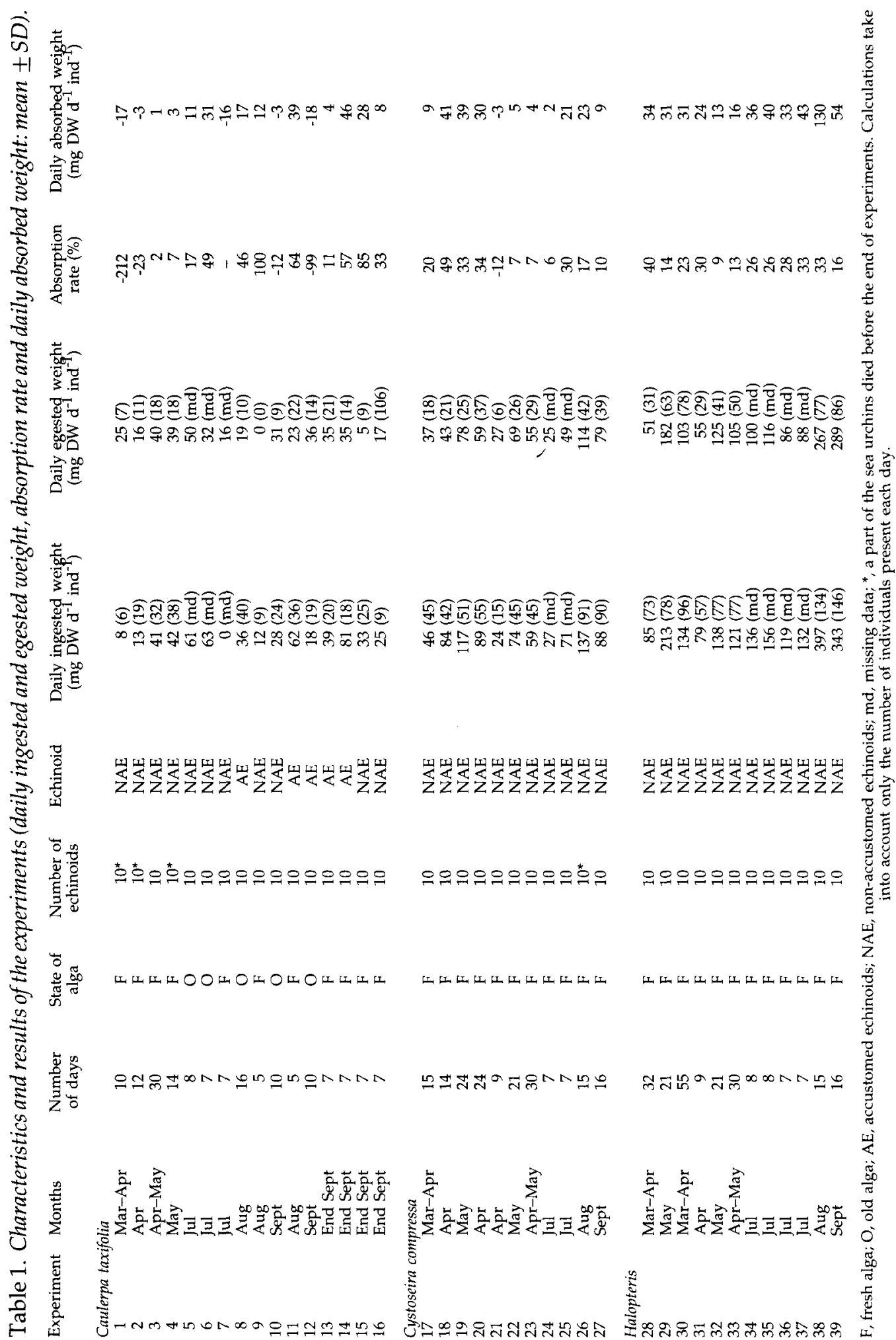


Faeces (egested material) were collected daily with a siphon system, sorted (elimination of spines and unconsumed algal fragments that had fallen through the plastic grid) then drained between filter papers before being dried $\left(70^{\circ} \mathrm{C}\right)$ for $<24 \mathrm{~h}$ and weighed to the nearest $0.01 \mathrm{~g}$ DW. The egested weight was obtained by the difference between the weight of the dried filter paper with faeces and the initial weight of the dried filter paper.

The absorption rate (AR), the percentage of ingested material moving through the intestinal wall, was calculated using the following equation:

$$
\mathrm{AR}=\frac{\text { (dried ingested weight-dried egested weight }) \times 100}{\text { dried ingested weight }}
$$

The daily absorbed weight is the difference between the dried ingested weight and the dried egested weight.

Non-parametric variance analysis (Kruskal \& Wallis test in Conover, 1980) was performed in order to assess whether the food (C. taxifolia, Cystoseira compressa, $\mathrm{H}$. scoparia) might have an influence on the different parameters measured (daily ingested weight, daily egested weight, absorption rate and daily absorbed weight). To assess a possible seasonal influence on absorption rate and daily absorbed weight, a Mann \& Whitney non-parametric test was performed (Conover, 1980). In addition, two-way ANOVA, fixed effects (software Statistica) was performed on the ingestion data in order to take into account several factors, such as the state of the plant (fresh or old) or the echinoid ability to become accustomed to Caulerpa taxifolia (accustomed echinoid, non-accustomed echinoid), and their interactions with regard to the feeding behaviour of $P$. lividus.

\section{RESULTS AND DISCUSSION}

Table 1 presents the results obtained on average daily ingested weight, average daily egested weight, absorption rate and average daily absorbed weight of different echinoid groups, fed on each alga at different seasons, usually during short periods of time (1-3 weeks).

The highest daily ingestions were recorded for Halopteris scoparia (from 79 to $397 \mathrm{mg}$ DW d $\mathrm{d}^{-1}$ ind $^{-1}$ ). For Cystoseira compressa, the average daily ingestion ranged between 24 and $137 \mathrm{mg} \mathrm{DW} \mathrm{d}^{-1}$ ind $^{-1}$ and for Caulerpa taxifolia, between 0 and $81 \mathrm{mg} \mathrm{DW} \mathrm{d}^{-1}$ ind $^{-1}$. These data are higher than or consistent with what has been reported in the literature for Paracentrotus lividus kept in aquarium. Mastaller (1974) recorded a Fucophycae ingestion rate ranging from 66 to $146 \mathrm{mg} \mathrm{DW} \mathrm{d}^{-1}$ ind $^{-1}$; Frantzis \& Grémare (1992) gave for Cystoseira compressa from 15 to $70 \mathrm{mg} \mathrm{DW} \mathrm{d}^{-1} \mathrm{ind}^{-1}$, for Halopteris scoparia, between 25 and $100 \mathrm{mg} \mathrm{DW} \mathrm{d}^{-1}$ ind $^{-1}$. For Caulerpa taxifolia, Lemée et al. (1994a) recorded ingestion rates from $25 \mathrm{mg} \mathrm{DW} \mathrm{d}^{-1}$ ind $^{-1}$ in winter-spring to $50 \mathrm{mg} \mathrm{DW} \mathrm{d}^{-1}$ ind $^{-1}$ in summer-autumn (their wet weight values have been transformed with our wet weight/dry weight relation); after three months of experiments, these rates increase up to $100 \mathrm{mg} \mathrm{DW} \mathrm{d}^{-1}$ ind $^{-1}$ in winter-spring and fall in summer-autumn $(<5 \mathrm{mg} \mathrm{DW}$ $\mathrm{d}^{-1}$ ind $\left.^{-1}\right)$. Amounts of egested faeces follow the same overall pattern as the ingestion: 
from 51 to $289 \mathrm{mg} \mathrm{DW} \mathrm{d}^{-1}$ ind $^{-1}$ for $H$. scoparia, from 25 to $114 \mathrm{mg} \mathrm{DW} \mathrm{d}^{-1}$ ind $^{-1}$ for Cystoseira compressa and from 0 to $50 \mathrm{mg} \mathrm{DW} \mathrm{d}^{-1}$ ind $^{-1}$ for Caulerpa taxifolia. Results of the Kruskal-Wallis test show that the species of alga given to the sea urchins acts significantly on the daily ingested weight $(\mathrm{H}=24.98, P=0.0001)$ and on the daily egested weight $(\mathrm{H}=26 \cdot 48, P=0.0001,99 \%$ confidence limit interval). Thus $P$. lividus' ingestion rate depends on the alga the sea urchin is supplied with. Halopteris scoparia is preferred to Cystoseira compressa, itself preferred to Caulerpa taxifolia. In Fucophycae, chemical defences seem to be linked to the presence of polyphenolic compounds (Lüning, 1990). They form indigestible complexes with proteins in the grazer's gut and thus decrease the digestibility of the ingested material (Feeny, 1976; Rhoade \& Cates, 1976). Grazers appear to consume preferentially macrophytes whose content in phenolic compounds is the weakest. The phenol content of Cystoseira compressa might explain the behaviour of $P$. lividus toward this alga, which contains a high level of polyphenolic compounds compared to other macrophytes: $22.75 \pm 5.98 \%$ of dry weight for C. compressa vs $1.77 \pm 0.04 \%$ for $H$. scoparia (Frantzis \& Grémare, 1992). In the Chlorophyta Caulerpa taxifolia, the presence of caulerpenyne might act on the feeding behaviour of the sea urchin. Its caulerpenyne content, in situ at Cap Martin (Alpes-Maritimes, France), varies over the year, decreasing from $2 \mathrm{mg} \mathrm{g}^{-1} \mathrm{WW}$ in July to $0.6 \mathrm{mg} \mathrm{g}^{-1} \mathrm{WW}$ in January, then to $0.2 \mathrm{mg} \mathrm{g}^{-1} \mathrm{WW}$ at the end of April, according to Guerriero et al. (1994). However, there is no significant seasonal variation of the ingested weight for any of the three algae used in these short duration experiments (Mann-Whitney test with a 95\% confidence limit interval: $Z=-0.866, P=0.386$ for C. taxifolia; $Z=-0.378, P=0.705$ for Cystoseira compressa; and $Z=-1.281, P=0.200$ for $H$. scoparia). The same pattern is observed with the daily egested weight (MannWhitney test with a 95\% confidence limit interval: $Z=-1.888, P=0.059$ ) for Caulerpa taxifolia; $Z=-0.567, P=0.571$ for Cystoseira compressa; $Z=-0.641, P=0.522$ with $H$. scoparia). Calculations have only been made on data obtained with 'fresh' Caulerpa taxifolia (F) and 'non-accustomed echinoids' (NAE). A summer drop in C. taxifolia short-term consumption rate was described by Lemée et al. (1996), but this is only based on one experiment and is not supported by statistical tests. In the long-term, nevertheless, a similar decline of consumption rate in summer-autumn was well established by Boudouresque et al. (1996).

On the whole, absorption rates measured in our experiments (Table 1) are weak as compared to the data in the literature. Lawrence (1975) gave rates between 60 and $70 \%$; according to this author, absorption affects the inorganic matter as well as the organic matter of the plant. For P. lividus, Frantzis (1992) obtained absorption rates between 76 and $86 \%$ when the echinoid fed on Cystoseira compressa, and between 31 and $70 \%$ when it fed on H. scoparia. For Strongylocentrotus franciscanus (Agassiz, 1863) from California, Vadas (1977) recorded rates ranging from 48 to $91 \%$. The absorption rate of the organic matter ranged, for the Californian Strongylocentrotus purpuratus (Stimpson), from 13\% (fed on Cystoseira osmundacea (Menzics) C. Agardh) to 62\% when it is fed on Macrocystis pyrifera (Turner) C. Agardh (data from Leighton, 1968 in Lowe \& Lawrence, 1976). For Lytechinus variegatus (Lamarck, 1816) from the American tropical Atlantic, the absorbtion rate is $\sim 43 \%$ fed on Halimeda incrassata Ellis, but it is negative $(-35 \%)$ when the sea urchin is fed on Eucheuma isiforme C. Agardh (Lowe \& 
Lawrence, 1976). So, absorption rate strongly varies according to the ingested plant. On the other hand, in our experiments, the Kruskal-Wallis tests (with a 95\% confidence limit interval), performed on parameters of $P$. lividus feeding behaviour, show that, for the three algae, the absorption rate does not significantly differ $(\mathrm{H}=0.56$, $P=0.756$ ). The difference is significant only for the daily absorbed weight (on average negative for Caulerpa taxifolia, $18 \mathrm{mg} \mathrm{DW} \mathrm{d}^{-1}$ ind $^{-1}$ with Cystoseira compressa and $25 \mathrm{mg}$ DW $\mathrm{d}^{-1}$ ind $^{-1}$ with Halopteris scoparia) with $\mathrm{H}=12.17$ and $P=0.002$. On the other hand, the absorption rate is significantly higher in summer-autumn than in spring for Caulerpa taxifolia (Mann-Whitney test with a 95\% confidence limit interval, $Z=-2 \cdot 121$, $P=0.034$ ). Thus for this alga, the toxic metabolite content, higher in summer-autumn (Lemée et al., 1993), would not decrease the absorption of ingested material, at least for short duration experiments. As far as the daily absorbed weight is concerned, there is no significant seasonal variation $(Z=-1.443, P=0.149)$. In any case, the absorption rate of sea urchins fed on $C$. taxifolia in spring is significantly different from the rate of sea urchins fed on control algae $(Z=-1.92, P=0.05$ for the comparison with Cystoseira compressa; $Z=-2.57, P=0.01$ for the comparison with $H$. scoparia). The differences are not significant in summer. During the warm season, in spite of a higher concentration of secondary metabolites of Caulerpa taxifolia (caulerpenyne rate suddenly increases when the water temperature exceeds $20^{\circ} \mathrm{C}$ according to Amade et al., 1996), P. lividus' absorption rate is practically the same whatever the ingested alga, during the first weeks of feeding. For P. lividus, Frantzis (1992) has not found important seasonal differences, except when the sea urchin was fed on $H$. scoparia: $31 \%$ in March and May vs $70 \%$ in July. Lawrence (1975), then Frantzis \& Grémare (1992), already noted a very high variability of absorption rates, given for different echinoid species, and a seasonal variability of these rates. In our experiments, some rates are even negative, especially when sea urchins are fed on C. taxifolia in spring. Lawrence (1975) also showed negative absorption rates when the sea urchins consumed algae containing tannins or alcaloids.

With regard to the $P$. lividus ability to become accustomed to $C$. taxifolia, the parametric tests (two-way ANOVA) performed on the ingestion data show that whatever the state of the alga (fresh or old), accustomed echinoids consume greater quantities of $C$. taxifolia than non-accustomed ones $(F=8.29 ; P=0.05)$. The interaction between the two factors is significant $(F=6.87 ; P=0.01)$; the contrast analysis then performed shows that the difference is especially due to the fresh alga (Figure 1). In these summer-autumn in vitro experiments (between 7 and $16 \mathrm{~d}$ ), accustomed echinoids feed more on fresh alga than on old, despite the fact that its toxicity decreases after several days spent in the aquarium (Lemée et al., 1993) and the high caulerpenyne rate in the fresh alga at this season (Amade et al., 1996). This feeding behaviour might show that caulerpenyne degradation products are as toxic as the whole molecule; Amade et al. (1996) observed a toxic effect on urchin eggs due to caulerpenyne degradation products.

This latter result shows that $P$. lividus, accustomed to $C$. taxifolia, can increase its consumption rate, without however reaching the rate obtained with almost totally avoided or preferred algae. Our results might suggest that if such ability to become accustomed also occurred in situ, $P$. lividus might become a potential consumer of 


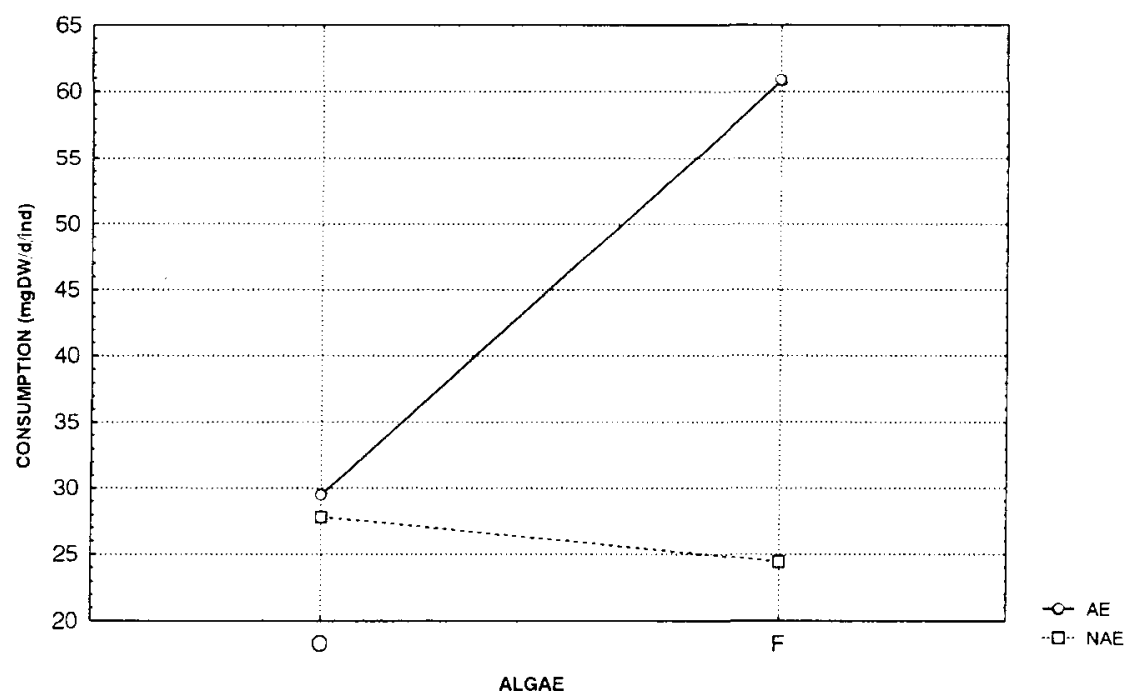

Figure 1. Consumption of Caulerpa taxifolia by Paracentrotus lividus according to the state of the alga and the echinoids. Algae, Caulerpa taxifolia; O, old; F, fresh; AE, accustomed echinoid; NAE, nonaccustomed echinoid.

C. taxifolia. Nevertheless, these experiments were performed over a short period, but in the long-term, Lemée et al. (1994b) and Boudouresque et al. (1996) have shown, both in the cold and warm seasons, a significant weakening of the sea urchins, up to death in summer-autumn.

In future experiments, it would be of interest to investigate, on the one hand, what are the mechanisms involved in becoming accustomed in the short term, and on the other hand, what are the factors that offset this trend in the long-term.

This work was supported by the French Ministère de l'Environnement and coordinated by Groupement d'Intèrêt Scientifique (GIS) Posidonie.

\section{REFERENCES}

Amade, P., Lemée, R., Pesando, D., Valls, R. \& Meinesz, A., 1996. Variations de la production de caulerpényne dans Caulerpa taxifolia de Méditerranée. In Proceedings of the Second International Workshop on Caulerpa taxifolia, Barcelona, Spain, December 1994 (ed. M.A. Ribera et al.), pp. 223-231. Spain: Publicacions Universitat Barcelona.

Ballesteros, E., Pou, S., Grau, A.M., Riera, F., Aranda, A., Pérez-Ruzafa, A. \& Rodrguez-Hiraldo, C., 1994. Primeros resultados de la campaña de sensibilización europea sobre la invasión de Caulerpa taxifolia (Vahl) C. Agardh. Situación en las costas mediterráneas españolas a finales de 1993. In Proceedings of the International Workshop on Caulerpa taxifolia, Nice, France, January 1994 (ed. C.-F. Boudouresque et al.), pp. 117-120. France: GIS Posidonie publications.

Belsher, T., Youenou, G., Dimeet, J., Raillard, J.M., Bertrand, S. \& Mereau, N., 1994. Éléments cartographiques et évolution de Caulerpa taxifolia en Méditerranée (Alpes-Maritimes et Monaco, 1992). Oceanologica acta, 17, 443-451.

Boudouresque, C.-F. et al., 1992a. The introduction of the green alga Caulerpa taxifolia into the Mediterranean: the repercussion for the indigenous communities. Mésogée, 52, 88-89.

Boudouresque, C.-F. \& Gómez-Garreta, A., 1992. El alga Caulerpa taxifolia (Chlorophyta) en el Mediterráneo occidental. Algas, 10, 3-8. 
Boudouresque, C.-F., Meinesz, A., Verlaque, M. \& Knoepffler-Peguy, M., 1992b. The expansion of the tropical alga Caulerpa taxifolia (Chlorophyta) in the Mediterranean. Cryptogamie Algologie, 13, 144-145.

Boudouresque, C.-F., Lemée, R., Mari, X. \& Meinesz, A., 1996. The invasive alga Caulerpa taxifolia is not a suitable diet for the sea urchin Paracentrotus lividus. Aquatic Botany, 53, 245-250.

Conover, W.J., 1980. Practical non-parametric statistics, 2nd ed. New York: J. Wiley \& Sons Inc.

Feeny, P., 1976. Plant apparency and chemical defense. Recent Advances Phytochemistry, 10, 1-40.

Frantzis, A., 1992. Etude expérimentale des niveaux de consommation et d'utilisation des macrophytes et des détritus dérivés par deux invertébrés benthiques: Paracentrotus lividus (Echinoide, herbivore) et Abra ovata (Bivalve, dépositivore). PhD thesis, Université Aix-Marseille II, France.

Frantzis, A., Berthon, J.F. \& Maggiore, F., 1988. Relations trophiques entre les oursins Arbacia lixula et Paracentrotus lividus (Echinodermata regularia) et le phytobenthos infralittoral superficiel dans la baie de Port-Cros (Var, France). Scientific Reports of the Port-Cros National Park, 14, 91-140.

Frantzis, A. \& Grémare, A., 1992. Ingestion, absorption and growth rates of Paracentrotus lividus (Echinodermata: Echinoidea) fed on different macrophytes. Marine Ecology Progress Series, 95, 169-183.

Gobert, J., 1992. Effet de la diffusion des substances émises par Caulerpa taxifolia sur le comportement alimentaire de l'oursin Paracentrotus lividus et étude de la place de Caulerpa taxifolia dans les préférences alimentaires de l'oursin Paracentrotus lividus. Report. Université Paris VI, France.

Guerriero, A., D'Ambrosio, M., Guella, G., Dini, F. \& Pietra, F., 1994. Secondary metabolites of the green seaweed Caulerpa taxifolia introduced into the Mediterranean sea, and a comparison with ciliates of the genus Euplotes. In Proceedings of the International Workshop on Caulerpa taxifolia, Nice, France, January 1994 (ed. C.-F. Boudouresque et al.), pp. 171-175. France: GIS Posidonie Publications.

Guerriero, A., Meinesz, A., D'Ambrosio, M. \& Pietra, F., 1992. Isolation of toxic and potentially toxic sesqui and monoterpenes from the tropical green seaweed Caulerpa taxifolia which has invaded the region of Cap Martin. Helvetica Chimica Acta, 75, 1-7.

Kempf, M., 1962. Recherches d'écologie comparée sur Paracentrotus lividus (Lmk) et Arbacia lixula (L.). Recueil des Travaux de la Station Marine d'Endoume, 25, 47-116.

Komatsu, T., Meinesz, A. \& Buckles, D., 1994. Données préliminaires sur l'influence de la température et de la lumière sur le développement et la croissance de Caulerpa taxifolia en culture. In Proceedings of the International Workshop on Caulerpa taxifolia, Nice, France, January 1994 (ed. C.-F. Boudouresque et al.), pp. 301-307. France: GIS Posidonie Publications.

Lawrence, J.M., 1975. On the relationships between marine plants and sea urchins. Oceanography and Marine Biology. Annual Review, 13, 213-286.

Leighton, D.L., 1968. A comparative study of food selection and nutrition in the abalone, Haliotis rufescens Swainson, and the purple sea urchin Strongylocentrotus purpuratus Stimpson. PhD thesis, University of California, San Diego, USA.

Lemée, R., Boudouresque, C.-F., Gobert, J., Malestroit, P., Mari, X., Meinesz, A., Ménager, V. \& Ruitton, S., 1996. Feeding behaviour of Paracentrotus lividus in the presence of Caulerpa taxifolia introduced in the Mediterranean sea. Oceanologica Acta, 19, 245-253.

Lemée, R., Boudouresque, C.-F., Mari, X. \& Meinesz, A., 1994a. Comportement alimentaire de Paracentrotus lividus vis à vis de Caulerpa taxifolia introduite en Méditerranée occidentale (étude in vitro). In Proceedings of the International Workshop on Caulerpa taxifolia, Nice, France, January 1994 (ed. C.-F. Boudouresque et al.), pp. 239-243. France: GIS Posidonie Publications.

Lemée, R., Boudouresque, C.-F., Mari, X. \& Meinesz, A., 1994b. Influence d'une nourriture exclusive à base de Caulerpa taxifolia sur la physiologie de Paracentrotus lividus. In Proceedings of the International Workshop on Caulerpa taxifolia, Nice, France, January 1994 (ed. C.-F. Boudouresque et al.), pp. 245-249. France: GIS Posidonie Publications.

Lemée, R., Pesando, D., Durand-Clément, M., Dubreuil, A., Meinesz, A., Guerriero, A. \& Pietra, F., 1993. Preliminary survey of the toxicity of the green alga Caulerpa taxifolia introduced into the Mediterranean. Journal of Applied Phycology, 5, 485-493. 
Lowe, E.F. \& Lawrence, J.M., 1976. Absorption efficiencies of Lytechinus variegatus (Lamarck) (Echinodermata: Echinoidea) for selected marine plants. Journal of Experimental Marine Biology and Ecology, 21, 223-234.

Lüning, K., 1990. Seaweeds. Their environment, biogeography and ecophysiology (ed. C. Yarish and H. Kirkman). New York: J. Wiley \& Sons Inc.

Mastaller, M., 1974. Zerstörung des Makrophytals an der nordadriatischen küste durch intensives Abweiden durch Seeigel, eine Untersuchung über Populationsstrukturen nahrung und fressverhalten bei dem Echinoiden Paracentrotus lividus ( $L m k$ ). PhD thesis, Zoologie Institute, Universität München, Germany.

Meinesz, A. \& Hesse, B., 1991. Introduction et invasion de l'algue tropicale Caulerpa taxifolia en Méditerranée nord-occidentale. Oceanologica Acta, 14, 415-426.

Meinesz, A. et al., 1993a. Suizi de l'invasion de l'algue tropicale Caulerpa taxifolia en Méditerranée. Situation au 31 Décembre 1992. France: University of Nice Publication.

Meinesz, A. \& Vaugelas, J. de, Hesse, B., Mari, X., 1993b. Spread of the introduced tropical green alga Caulerpa taxifolia in northern Mediterranean waters. Journal of Applied Phycology, 5, 141-147.

Meinesz, A. et al., 1994. Suivi de l'invasion de l'algue tropicale Caulerpa taxifolia devant les côtes Françaises de la Méditerranée. Situation au 31 Décembre 1993. France: LEML-UNSA Publication.

Meinesz, A. et al., 1995. Suivi de l'invasion de l'algue tropicale Caulerpa taxifolia devant les côtes Françaises de la Méditerranée. Situation au 31 Décembre 1994. France: LEML-UNSA Publication.

Morucci, C., Sandulli, R., Tripaldi, G., Casolino, R., Cinelli, F., Proietti-Zolla, A., BenedettiCecchi, L. \& Della Pieta, F., 1994. Primi risultati della campagna di sensibilizzazione e localizzazione attiva europea sulla propagazione di Caulerpa taxifolia. Situazione lungo le coste italiane alla fine del 1993. In Proceedings of the International Workshop on Caulerpa taxifolia, Nice, France, January 1994 (ed. C.-F. Boudouresque et al.), pp. 127-132. France: GIS Posidonie publications.

Pou, S., Ballesteros, E., Delgado, O., Grau, A.M., Riera, F. \& Weitzmann, B., 1993. Sobre la presencia del alga Caulerpa taxifolia (Vahl) C. Agardh (Caulerpales, Chlorophyta) en aguas costeras de Mallorca. Bolleti Societat História Naturals Balears, 36, 83-90.

Powis de Tenbossche, T., 1978. Comportement alimentaire et structures digestives de Paracentrotus lividus. Mémoire Licence Sciences Zoolgie, Université libre Bruxelles, Faculté des Sciences.

Rhoade, D.F. \& Cates, R.G., 1976. Toward a general theory of plant antiherbivore chemistry. Recent Advances Phytochemistry, 10, 168-213.

Rico, V., 1989. Contribution à l'étude des preferenda alimentaires et du comportement moteur de l'oursin régulier Paracentrotus lividus. Mémoire DEA, Université Aix-Marseille II, France.

Ruitton, S. \& Boudouresque, C.-F., 1994. Impact de Caulerpa taxifolia sur une population de l'oursin Paracentrotus lividus à Roquebrune-Cap Martin (Alpes-Maritimes, France). In Proceedings of the International Workshop on Caulerpa taxifolia, Nice, France, January 1994 (ed. C.-F. Boudouresque et al.), pp. 371-378. France: GIS Posidonie publications.

Traer, K., 1980. Ernährung und energetik regulärer Seeigel in beständen des mediterranen Seegrases Posidonia oceanica. PhD thesis, Formal und Naturwissenchafteichen Fakültat der Universität Wien, Austria.

Vadas, R.L., 1977. Preferential feeding: an optimization strategy in sea urchins. Ecological Monographs, 47, 337-371.

Vaugelas, J. de, Blachier, J., Cottalorda, J.M., Komatsu, T., Lemée, R., Meinesz, A., Molenaar, H. \& Pietkiewicz, D., 1994. Premiers résultats de la campagne de sensibilisation européenne sur l'invasion de Caulerpa taxifolia. Situation sur les côtes françaises de la Méditerranée à la fin de 1993. In Proceedings of the International Workshop on Caulerpa taxifolia (ed. C.-F. Boudouresque et al.), pp. 121-125. France: GIS Posidonie publications.

Verlaque, M., 1987. Relation entre Paracentrotus lividus (Lamarck) et le phytobenthos de Méditerranée occidentale. In Proceedings of the International Workshop on Caulerpa taxifolia (ed. C.-F. Boudouresque et al.), pp. 5-36. France: GIS Posidonie publications.

Verlaque, M. \& Nédélec, H., 1983. Biologie de Paracentrotus lividus sur substrat rocheux en Corse: alimentation des adultes. Vie et Milieu, 33, 191-201.

Villèle, X. de \& Verlaque, M., 1995. Changes and degradation in a Posidonia oceanica bed invaded by the introduced tropical alga Caulerpa taxifolia in the northwestern Mediterranean. Botanica Marina, 38, 79-87. 